\title{
NOTES
}

\section{WHITMAN VIEWED BY TWO SOUTHERN GENTLEMEN}

Over the years, Whitman has been criticized adversely in all parts of the country, but one section, the Southland, stands out as the most adamant and unanimous in its condemnation. In his bibliography of writings on Whitman (Walt Whitman, 1838-1939: A Reference Guide [Boston: G. K. Hall, 1981]), Scott Giantvalley lists only two Southern articles dealing with Whitman up to and including 1860 . One of these is reported to be a review of Leaves of Grass, published in the New Orleans Weekly Mirror on 9 June 1860. Copies of this newspaper for that date have not been located, so it is impossible to determine whether the review was favorable or unfavorable. The other entry in Giantvalley's bibliography is more accessible:

\section{ANON. "A New American Poem." Southern Field and Fireside, (9 June), 20.}

Giantvalley did not know that the author of this unsigned article was John R. Thompson, who had won national recognition as the editor and/or owner of the Southern Literary Messenger. After thirteen years in the chair once occupied by Edgar Allan Poe, Thompson gave up the job to accept that of Literary Editor of the Southern Field and Fireside, a family paper published in Augusta, Georgia. This might appear to be a step downward, but actually it was an advantageous move, for it paid a better salary for less work.

One of Thompson's first contributions to the Southern Field and Fireside was this unsigned editorial in the issue for 9 June 1860, essentially a review of the third edition of Leaves of Grass, published a few weeks earlier.

\section{A New American Poem}

It has been a favorite subject of complaint with English critics and reviewers, in treating of American civilization, that in this country we have produced as yet no peculiar, distinctive literature of our own, and that all our efforts in polite letters have been but feeble imitations of English originals, lunar reflections, as it were, of that intellectual sun which, we are told, still rises for us over the Atlantic. Thus, they allege, we refer to Cooper as "the American Scott," Emerson is Carlyle and water (and very muddy water, in the present writer's humble judgment), the North American Review is a poor copy of the Edinburgh, and so forth. But especially do they reproach us with a lack of originality in the poetical form of composition. There is fancy and sweetness and music, they admit, in our poets, but we can point to no one great poem on which is stamped the impression of a new and mighty continent, which is fragrant with the fresh odours of the unpruned forest, whose rhythm, mighty in its movement as the wind rushing over the limitless prairie, bears the reader along unresistingly-a poem, in short, full of the energy, the passion, the vim of large-veined, stout-breasted, hopeful, wideawake, go-ahead Young America. But the reproach can be made no longer. We have an American poem. Several of them. Yes, sir. Also a great original representative mind. 'The hour and the man' have arrived, the man who knows what's o'clock and always comes up to time. The name of this wonderful poet is Walt Whitman, and his verdant volume of verse is called "Leaves of Grass." 
Perhaps we are wrong in referring to these "leaves" as verse. We used that term for want of a better one, and having in mind the definition of the master in the Bourgeois Gentilhomme-Tout-ce qui n'est point prose est vers, et cout-ce qui n'est point vers est prose. Worthy Monsieur Jourdain was astonished, as Molière makes him confess, to discover that he had been speaking prose all his life without knowing it, but the master would have experienced a much greater degree of amazement, could he have seen his theory demolished by a poem like any one of these by Walt Whitman. Here is something which is neither prose nor verse, which writes itself out in long or short sentences, as the case may be, disdaining the shackles of rhyme or measure, and sounding to the ear alternately like the click of the instrument in the Telegraph office, the roar of Buttermilk Falls, the eloquence of the Razor-Strop man, the buzz of a wheat-machine, the braying of an ass, the cries of 'the boys' running to a big fire with No. 40, the animated evening conversation in a Lager Bier Saloon, and a campaign speech in the House of Representatives.

Mr. Walt Whitman is to us, however, no "new Nebuchadnezzar," nor has the "Leaves of Grass" been brought to our notice now for the first time. Five years ago we recollect to have seen the first edition of it, and to have made up our mind that if it did not proceed from a lunatic, it was designed as a solemn hoax upon the public. The extravagance of the style, the beastliness of the sentiments, the blatant blasphemy of the whole performance, its profanation of every tender and holy impulse, its frequent indecency of language, all suggested Bedlam. The bizarre appearance of the book also indicated a crazy origin. The page, about half the size of our own, was printed in type as large as that of a playbill, the presswork seemed to have been done with a sledgehammer, and the frontispiece was adorned with a full length portrait, in the finest steel engraving, of Walt Whitman, in which, without other garment than shirt and pantaloons, his sleeves rolled up and arms akimbo, he appeared to be doing his best to look like a rowdy and a vagabond, and with greater success, it must be admitted, than ordinarily falls to human endeavour.

After the lapse of a lustrum, not so long a time as was recommended by the Latin critic for keeping a poem before publication, the profane, bestial rigmarole is again brought before the public, enlarged, altered and rendered, if possible, more disgusting and abominable than in its pristine shape. If the present edition had excited no more comment than the first, we should not have taken the trouble to refer to it. But it has been widely noticed and even applauded, an immense amount of advertising has been expended upon it by the publishers, and there is danger that it may find its way into respectable bookstores and even pure households, by reason of the attention that it has received. To save the latter from moral contamination and the necessity of using disinfectants, we feel bound to say so much by way of caution as will enable them to learn the true character of the volume. Not that we would pollute our columns with quoting any of its vilest passages. It will suffice, we hope, to say that Walt Whitman glories in materialism of the most degraded kind, that the animal passions call forth his loftiest admiration, and that man as a brute, in his earthly relation to the beasts that perish, not in his kinship to immortal beings, is the object of that faculty which in the Walt Whitman organization takes the place of reverence. Not only is he without the means of discriminating between the pure and the impure, but the Chevalier Bayard is no more to him than a chickencock, Tennyson is no higher in the scale of created things than a tadpole, and he can perceive no difference between Bacon and a Berkshire pig.

And yet all this is mixed up with constant references to the soul, of which he assumes to be an interpreter. Hear what he says of himself-

- No dainty dolce affetuoso I;

Bearded, sunburnt, gray-necked, forbidding I have arrived. 
I pass death with the dying, and birth with the new-washed babe, and am not contained between my hat and my boots.

I exist as I am-that is enough,

If no other in the world be aware, I sit content.

And if each and all be aware, I sit content.

I am the poet of the body

And I am the poet of the soul.

The pleasures of heaven are with me, and the pains of hell are with me,

The first I graft and increase upon myself-the latter I translate into a new tongue.

I know perfectly well my own egotism.

I am an acme of things accomplished and I am an enclosure of things to be.

A clever parodist in the New York Albion, thus imitates Walt Whitman in lines which he will find it difficult to tell from his own.

I tell you the truth. Salut!

I am not to be bluff'd off. No, Sir.

I am large, hairy, sprawling, big in the shoulders, narrow in the flank, strong in the knees, and of an inquiring and communicative disposition.

Also instructive in my propensities, given to contemplation, and able to lift anything that is not too heavy.

Listen to me, and I will do you good,

Loafe with me, and I will do you better.

And if any man dares to make fun of me, I shall be after him with a particularly sharp stick.

Vale! ${ }^{1}$

The following from "Leaves of Grass" has been cited by a very competent critic as a fine specimen of "power, pathos and music." 2 It is a funeral piece-

Cold dash of waves at the ferry-wharf-posh and ice in the river, half-frozen mud in the streets, a gray, discouraged sky overhead, the short last daylight of Twelfth Month.

A hearse and stages - other vehicles give place-the funeral of an old Broadway stage driver, the cortege mostly drivers.

Steady the trot to the cemetery, duly rattles the death-bell, the gate is passed, the new-dug grave is halted at, the living alight, the hearse uncloses,

The coffin is passed out, lowered and settled, the whip is laid on the coffin, the earth is swiftly shovelled in.

The mound above is flatted with the spades-silence,

A minute, no one moves or speaks-it is done,

$\mathrm{He}$ is decently put away-is there anything more?

He was a good fellow, free-mouthed, quick-tempered, not badlooking, able to take his own part, witty, sensitive to a slight, ready for life or death for a friend, fond of women, gambled, ate hearty, drank hearty, had known what 
it was to be flush, grew low-spirited towards the last, sickened, was helped by a contribution, died, aged fortyone years-and that was his funeral.

We very frankly confess ourselves unable to recognize the force, the feeling, or the melody of the passage. The last line or strophe or stanza, or whatever it may be, is a good portraiture, but we like this from the Albion much better-

Once I knew a man.

Not that man.

But another man.

A man I once knew. He was great, was glorious, nev'r washed hair, n'r combed his face,-'mean combed face n'r washed hair; had big han's-dirty-'n big feet-dirty,-red'n freckled, 'cause didn't wear hat, n'r coat, n'r shoes, but went bare headed 'n bare footed, 'n shirt 'n pants like free 'n in-in-in'pen't citiz'n these 'nited States.

'Swear he was glorious.

This is no bad picture in words of the steel engraving of Walt Whitman himself, in the first edition of "Leaves of Grass."

In dismissing the consideration of this new American poem, let us say that we think we can discern the reason why it has been raked up from its long sleep among the buried corruptions of the past. Walt Whitman is the poet of prize-fighters, the minstrel of muscle; his is the song of sinews, the burthen of brawn, and he thinks naturally enough that the age and generation which could delight in the Mill of the Champions, must applaud the apotheosis of brute strength. Among the Heenan-ities of the day, his verse may find admirers, but with all the votaries of pure literature, he must be greeted with a "Procul, procul este profani!" 33

It is unlikely that most readers of the Southern Field and Fireside had ever read Leaves of Grass, but there was one who had, Paul Hamilton Hayne, the Charleston poet and a regular contributor to the paper. On reading Thompson's article on Whitman, he immediately wrote to congratulate the new editor. Rayburn S. Moore was mistaken, however, in stating that:

Hayne's earliest reference to Whitman occurred in a letter to John R. Thompson . . . : "your critique upon Mr. Walt Whitman," he observed on 10 June, "delighted me beyond measure! The comparative success of his work demonstrates the lowness both of morals \& critics of the North."4

Moore failed to notice that, in the same issue of 9 June 1860 containing Thompson's editorial, Hayne himself published an article in which he attacked Whitman in terms quite similar to those used by Thompson.

Hayne's first contribution to Southern Field and Fireside was a sonnet published in the fifth issue, dated 25 June 1859. In the issue for 17 March 1860, he began a long series of articles, best described by the title: "The Whittington Club: or Dialogues upon Literature, With Special Reference to Current Publications." In the introduction Hayne explained that the participants in these dialogues were to be Frank Whittington, his close friend, Henry Bishop, occasionally Mrs. Whittington and 
"whatever accidental auxiliaries might drop in upon us during the nights for debate." In a note, Hayne added:

The writer's purpose is to enliven his comments upon books, by presenting the natural, unstudied action of different minds, exercised upon similar topics. He does not hold himself altogether responsible for the opinions of his small circle of "dramatis personae," although he would have the reader to understand that the views expressed by Whittington generally coincide with his own. ${ }^{5}$

The tenth installment of "The Whittington Club" appeared in the issue for 9 June 1860 . The scene, as described in a prefatory note by Hayne, was:

Whittington's Library. A supper-table covered with fruits and wines, around which are sitting Mr. Henry Bishop, Frank Whittington, and an accidental guest of the latter, Mr. J. Debritt Davis, who professes to be a transcendental Philosopher and Poet, \&c.

The group first discusses Thomas Hood's novel, Tylney Hall, which Bishop greatly admires. Davis, although he admits he has not read the book, is sure it is "an inferior production," since Hood is such a poor poet. Davis then proceeds to read a poem of his own composition, entitled "Despair," which he says exemplifies his preference for "grand bursts of passion and emotion, set to the rhythm of thunderous melodies." At this point, the dialogue continues with a change of subject.

Bishop. -A poet has just arisen at the North, who, in a wonderful book, styled "Leaves of Grass," has admirably fulfilled many of the artistic conditions you have mentioned. Of course, I allude to Mr. Walt Whitman!

Davis. - A great Heart, truly, sir! A comprehensive, yet incomprehensible Nature!

Whittington. - That is, like the universe we inhabit, his genius comprehends (or includes) humanity, but is not to be comprehended by it!

Davis. - Precisely; his "Leaves of Grass" I have not had the felicity of perusing, but an acquaintance with his other works assures me of his endowments as an out-seeing and in-seeing philosopher, a genuine lyric bates [sic]. But, pray, gentlemen, dispense with my presence for a season. I must join your charming lady, Mrs. Whittington, in the drawing room. It is my habit to spend at least one hour every day in the company of woman. I find my aspirations and instincts greatly intensified thereby. Magnetic rapport with the female mind results always in spiritual emphasis!

(Exit Mr. Davis, who is soon engaged solemnly instructing Mrs. Whittington upon "the aesthetics of female influence, magnetically and spiritually considered.")

Bishop. - Hum! If I may ask, who is that -that gentleman? A remarkable person, certainly! Whittington. - My dear fellow, I know substantially as little of him as you do, my knowledge amounting simply to this: Mr. Davis called upon me yesterday with a note of introduction from an acquaintance of mine in $\mathrm{W}^{\star \star}$. I asked him to supper, hoping he might prove a pleasant acquaintance to our club.

Bishop. - Pleasant, indeed; is the creature "daft"? I strongly suspect you have had some unfortunate member of the lunatic asylum imposed by mistake upon you! I trust he isn't dangerous!

Whittington.-P'shaw! The man is simply drunk with egotism, folly and conceit! He is a somewhat ultra specimen of a class of would-be philosophers and poets, who are at present shocking the intelligent portion of our public by every species of monstrous exaggeration in thought, fancy, language and morality. The writer you mentioned a moment since, $(\mathrm{Mr}$. Walt 
Whitman,) illustrates more fully the nature of the literature I am condemning. When I see such a work as his "Leaves of Grass" gravely commended by critics of reputation, I begin to fear that the literary character of this country is becoming as hopelessly perverted and rotten as the political. If Mr. Walt Whitman is a poet, and a truly philosophical poet to boot, why, in heaven's name let us at once reverse all our former critical and aesthetical judgments; every other author hitherto viewed as standard (especially every poet) must be cast into the fire; clearness of imagination and conception, purity of diction, loftiness of tone, and grandeur of moral insight, must henceforth give place to the most hideous manifestations of morbid egotism, and introspective vanity, united to an unmorality so complete, that all distinctions between vice and virtue, purity and filthiness, fail to be understood; and man is finally reduced to the level of a being swayed by eternally conflicting instincts, in the gratification of which (so far as gratification is possible), he nobly follows out the original laws, and attains to the proper ends of his existence! In fact, to one calmly reviewing these "Leaves of Grass," the great matter for astonishment - as a sensible northern critic has dared to say -is, that any individual could be found capable of drawing so slender a thread of purity and truth through such a vile mass of folly, feculence and falsehood.

Bishop. - On this point, you speak, I am sure, the sentiment of every man who refuses to submit his native good sense to the dictates of a transient fashion, or conform to the revolting literary affectations of the day. But let us waste no more time with Mr. Walt Whitman; in truth, so atrocious a blackguard could hardly have claimed our notice at all, for whatever of talent he does possess, it is his constant endeavor to drown it in an immense black pool of filth and blasphemy [...]

At this point, the discussion turns to another subject, Voyage down the Amoor, a book on travel in Russia. The description of a Cossack house has horrified Bishop. The dialogue then concludes:

Whittington.-By the way, this description of the Cossack huts is singularly apropos. Bishop. - How?

Whittington. - I mean that it is precisely in such a position of morals, dirt, degradation, and promiscuousness, that the writer of "Leaves of Grass," (which "to-day are, and to-morrow will surely be thrown into the oven' of oblivion) is aiming to bring society by the great doctrine of the immorality and sufficiency of instinct, as well as his seeming readiness to carry out his doctrine into the most emphatic practice!

So far as is known, Thompson never again expressed his views on Whitman. Nor for that matter did Hayne-for publication. In his personal letters, however, he returned again and again to his dislike of "The big shameless Beast." In the article cited above, Rayburn S. Moore said that "Hayne's opinion of Whitman changed little over a period of twenty-five years," adding, "After all, Hayne was, in effect, writing a majority report for his generation." Perhaps so, but few enemies of Whitman could equal him for violence or dogged persistence. If Guinness had a category for haters, Hayne would surely receive a high ranking in it.

Vanderbilt University

W. T. BANDY

\section{NOTES}

1 "Parody." Albion, 38 (26 May 1860), 249. This unsigned parody is by Richard Grant White. 
2 The "very competent critic" has not been identified.

3 Southern Field and Fireside, 2, No. 3 (9 June 1860), 20.

4 Rayburn S. Moore, "The Literary World Gone Mad: Hayne on Whitman," The Southern Literary fournal, 10, No. 1 (Fall 1977), 76.

5 Southern Field and Fireside, 1, No. 43 (17 March 1860), 338.

\section{WHITMAN ON WAR: FOUR POEMS FROM DRUM-TAPS}

The order in which the poems of Leaves of Grass appear is often of dubious significance, despite Whitman's occasional claims to the contrary; but at times it is crucial. Perhaps most notably in the Drum-Taps section of the book, sequence frequently enriches and enhances meaning: particular poems are best seen not in isolation, but as part of an ordered and purposeful development.

Such a sequence is the series of four poems beginning with "Cavalry Crossing a Ford" and including "Bivouac on a Mountain Side," "An Army Corps on the March," and "By the Bivouac's Fitful Flame." All are of approximately equal length, ranging from seven to ten lines, and their arrangement is neatly symmetrical. As the titles indicate, there are two poems involving motion ("Crossing," "On the March"), each followed by a "bivouac" poem of stopping; the motion poems take place during the day, the bivouac poems during the night. The sunlight of one group is balanced by the firelight of the other. Comparing each poem with its counterpart reveals a progression of significant intent.

In "Cavalry Crossing a Ford" colors are a prominent feature: the green islands, the silvery river, the brown-faced men, the scarlet and blue and white of the flags. It is a lovely tableau, serene and undisturbed. The pace is leisurely: the horses, we are told, "loitering stop to drink," and among the men, "the negligent rest on their saddles" (my emphasis). It is a time when one can loiter and be negligent, when it is possible to enjoy the sunshine and the "musical clank" of movement. Everything in the poem suggests that these are new troops untried in battle; their weapons are so shiny that they "flash in the sun," and the white flags are still "snowy white," fluttering "gayly" in the wind. It is a time for gaiety; unpressed and unhurried, the troops pass through a lovely landscape, unmindful of what is to come.

In the second "motion" poem, "An Army Corps on the March," all has changed. Like the first, it contains sounds, but instead of the pleasing "musical clank" of "Cavalry Crossing a Ford," the sounds are threatening: we hear rifle shots and the ominous rumbling of wagon wheels. There is no loitering here, no opportunity for negligence; the troops are engaged in battle, and movement is forced and frantic ("the swarming ranks press on and on, the dense brigades press on"). The sun still shines, but there is no bright flashing and sparkle; the glittering, such as it is, is dim, and the men are dust-covered. We see no flags decorating the landscape, not even any individual men; only "swarming ranks" and "dense brigades." In "Cavalry Crossing a Ford" there was time to stop, so that each person could be seen as "a picture," but not here, where the frenzy of movement under attack enforces anonymity. Personal identity becomes, under the circumstances, irrelevant if not impossible. Instead of the delicate movements of "Cavalry Crossing a Ford," we 